\title{
Analysis of spatial and temporal expression patterns of bone morphogenetic protein family members in the rat uterus over the estrous cycle
}

\author{
G F Erickson, L Fuqua and S Shimasaki \\ University of California San Diego, Department of Reproductive Medicine, 9500 Gilman Drive 2058 CMME, La Jolla, California 92093-0674, USA \\ (Requests for offprints should be addressed to G F Erickson; Email: gerickson@ucsd.edu)
}

\begin{abstract}
Recent studies have demonstrated that bone morphogenetic proteins (BMPs) play fundamental roles in female fertility. This is particularly evident in terms of the ovary. One major question that is just beginning to be addressed is the role of BMPs in the non-pregnant uterus. To help fill this gap, we used in situ hybridization to investigate the expression of BMP family members in the rat uterus over the estrous cycle. We found that the endometrial/uterine cycle is accompanied by the expression of several components of the BMP pathway - including ligands, receptors and antagonists. The mRNAs encoding BMP receptors are expressed in the epithelial (BMP-RIA, -RIB and $-\mathrm{RII}$ ), periluminal stroma (BMP-RIA and -RII) and smooth muscle cells (BMP-RIA and -RII). The expression of all three receptors showed clear cyclic variations. The mRNAs encoding BMP ligands were highly ex-
\end{abstract}

pressed in the periluminal stroma (BMP-2 and -7) and glandular epithelium (BMP-7). The expression of BMP-2, but not BMP-7, was cyclical. Notably, the periluminal stroma expressed noggin mRNA. In the blood vascular system, BMP-4, -6 and -RII mRNAs were expressed in myometrial endothelial cells. Interestingly, follistatin, noggin, and BMP-4, -6 and -7 mRNAs were expressed in eosinophilic leukocytes, suggesting unexpected roles for eosinophil-derived BMPs in uterine function. We conclude that BMP ligands, receptors and antagonists are expressed in spatially and temporally restricted patterns that are consistent with a physiological role for these regulatory molecules in promoting uterine cellular processes including cell proliferation, differentiation and apoptosis during the cycle.

Journal of Endocrinology (2004) 182, 203-217

\section{Introduction}

Understanding the mechanisms regulating the endometrial cycle is an area of intense research because of its importance to normal fertility and reproductive function. During the menstrual and estrous cycles, the uterus undergoes cyclical changes that involve precise coordination of cell proliferation, differentiation and apoptosis in the endometrium and myometrium. The ovarian hormones, estrogen (Lubahn et al. 1993, Couse \& Korach 1999) and progesterone (Lydon et al. 1995, Graham \& Clarke 1997, Conneely et al. 2002, Rider 2002) play critical roles in coordinating uterine cellular processes during the cycle. In a broad sense, estrogen stimulates cell proliferation in the epithelial and stromal tissues of the endometrium during the proliferative phase while progesterone promotes glandular differentiation as well as inhibits both cell proliferation and myometrial contractile activity (Graham \& Clarke 1997). The primary purpose of the tissue remodeling in the non-pregnant uterus is to create an environment suitable for blastocyst implantation.
The functional responses to these steroid hormones are mediated by specific progesterone and estrogen receptor (PR and ER respectively) signaling pathways in uterine target cells (Graham \& Clarke 1997, Couse \& Korach 1999). In normal cycling rodents (Katsuda et al. 1999, Pelletier et al. 2000, Wang et al. 2000, Andersson et al. 2001, Mendoza-Rodríguez et al. 2003) and humans (Mertens et al. 2001, Punyadeera et al. 2003), ER $\alpha$ is the dominant subtype expressed in the uterus, being localized to the epithelium, stroma, myometrium and some blood vessels. By comparison, ER $\beta$ is more weakly expressed. Studies in knockout models indicate that ER $\alpha$, but not $\mathrm{ER} \beta$, is responsible for mediating estrogen action in the uterus (Couse \& Korach 1999). PR-A and PR-B are co-expressed in target cells of the rodent (Ohta et al. 1993, Hodges et al. 2002) and humans (Mote et al. 1999, Punyadeera et al. 2003, Arnett-Mansfield et al. 2004) being expressed in the epithelium, stroma and myometrium. PR-A is the predominant isoform in the mammalian uterus. Knockout studies indicate that PR-A, but not $\mathrm{PR}-\mathrm{B}$, is essential for eliciting progesterone-dependent responses in the uterus (Conneely et al. 2002). 
It has become increasingly clear that estrogen and progesterone do not operate in isolation, but rather function together with growth factors to control the uterine cycle. The most intensely studied and best understood growth factors are the insulin-like growth factors (Giudice et al. 1998, Wathes et al. 1998), transforming growth factor- $\beta$ (TGF- $\beta$; Godkin \& Dore 1998, Ingman \& Robertson 2002), TGF- $\alpha$ (Nelson et al. 1992), epidermal growth factor (Curtis et al. 1996, 1999), and the inhibin/ activin/follistatin proteins (Jones et al. 2002). The conclusion emerging from these investigations implicates locally produced growth factors as critical mediators of steroidhormone-dependent responses in the uterus (Pollard 1990, Cooke et al. 1997, Kurita et al. 2000).

With respect to the TGF- $\beta$ superfamily, considerable attention has been paid to the bone morphogenetic protein (BMP) family in regulating mammalian reproduction (Shimasaki et al. 2004). This attention is particularly intense in the ovary where BMP ligands (Dong et al. 1996, Galloway et al. 2000, Yan et al. 2001), BMP receptors (Mulsant et al. 2001, Souza et al. 2001, Wilson et al. 2001, Yi et al. 2001) and BMP-binding proteins (Guo et al. 1998) have been shown to be essential for normal folliculogenesis and female fertility. BMPs are the largest family of growth factors in the TGF- $\beta$ superfamily. The BMP ligands exert a wide range of physiological functions in the target cells (Hogan 1996, Wozney 1998, 2002, Botchkarev 2003, Canalis et al. 2003, Shimasaki et al. 2004) through binding to specific cell surface type I (BMP-RIA/ALK-3 and BMP-RIB/ALK-6) and type II (BMP-RII) serine/ threonine kinase receptors (Balemans \& Van Hul 2002, Shimasaki et al. 2004). Upon binding of the BMP ligand the type II receptor transphosphorylates the type I receptor, which in turn evokes BMP signaling through Smad-dependent pathways (Von Bubnoff \& Cho 2001, Shimasaki et al. 2004). In vertebrates a number of extracellular antagonists of BMPs have been identified that include noggin, chordin, follistatin, follistatin-related gene, ventropin, twisted gastrulation and the differential screening-selected gene aberrative in neuroblastoma (DAN) family members such as DAN, cerberus and gremlin (Balemans \& Van Hul 2002, Canalis et al. 2003). These BMP antagonists can prevent BMP signaling by binding BMPs, thus precluding their binding to specific cell surface receptors.

Although much is known about the expression of BMPs in the ovary (Erickson \& Shimasaki 2003), the question of the role for BMPs in uterine physiology is just beginning to be addressed. To date, most of the experimental investigations of uterine BMPs have used pregnant rodents. The general principle to emerge from this work is that the early stages of implantation and decidualization are characterized by the spatiotemporal pattern of expression of the mRNAs encoding several members of the BMP family. These include BMP-2 in the decidualizing stromal cells (Ying \& Zhao 2000,
Paria et al. 2001), BMP-4 and Smad1 in vascular endothelial cells (Ying \& Zhao 2000), BMP-7 in the endothelium and subjacent stroma (Ozkaynak et al. 1997, Paria et al. 2001), BMP-8a in decidual cells (Zhao \& Hogan 1996), BMP-RIB in the endometrium and endometrial glands (Yi et al. 2000), follistatin in decidual tissue (Kaiser et al. 1990, Mercado et al. 1993) and noggin and DAN in the stromal layer immediately underlying the luminal endothelium (Paria et al. 2001). This evidence has suggested that BMPs in the uterus have a potential role in pregnancy.

By comparison to the pregnant uterus, the expression and cellular consequences of the BMP family in the non-pregnant mammalian uterus remain largely unexplored. The purpose of this study is to fill this basic gap in our knowledge by analyzing the spatiotemporal pattern of expression of BMP ligands, receptors and binding proteins in the rat uterus over the estrous cycle.

\section{Materials and Methods}

\section{Animals}

Adult, female Sprague-Dawley rats (2-3 months of age) were housed under controlled lighting conditions $(14 \mathrm{~h}$ light: $10 \mathrm{~h}$ darkness; lights on from 0500 to $1900 \mathrm{~h}$ ) at $23{ }^{\circ} \mathrm{C}$; they were provided with formulated rat chow and water and were allowed to feed ad libitum. Vaginal smears were taken daily, and rats exhibiting two or more consecutive 4-day estrous cycles were used. The animals (two at each time of the cycle) were killed on proestrus (P1000 h and P2000 h: follicular phase), estrus (E0200 h and E1000 h: ovulatory phase), diestrus I (DI, $1100 \mathrm{~h}$ : luteal phase, luteinization) and diestrus II (DII, $1100 \mathrm{~h}$ : luteal phase, luteolysis). The rats were handled in accordance with the NIH Guide for the Care and Use of Laboratory Animals, and the protocols were approved by the University of California, San Diego Animal Subjects Committee.

\section{In situ hybridization}

In situ hybridization was performed as described previously (Erickson \& Shimasaki 2003). Sections $(10 \mu \mathrm{m})$ were hybridized with ${ }^{35}$ S-labeled RNA probe. After hybridization the slides were dehydrated in graded ethanol concentrations, immersed in Kodak NTB-2 photographic emulsion, air dried and exposed at $4{ }^{\circ} \mathrm{C}$ for 4 weeks. The slides were developed, fixed and stained with hematoxylin $(\mathrm{H})$ or hematoxylin and eosin $(\mathrm{H} \& \mathrm{E})$. The probes were prepared by RT-PCR using total RNA from adult rat ovaries. The primers were derived from the cDNA clones at the following nucleotide numbers: $511-528$ and 10661083 (accession number of the cDNA clone is M22489) for BMP-2 (Wozney et al. 1988); 878-897 and 1292-1311 


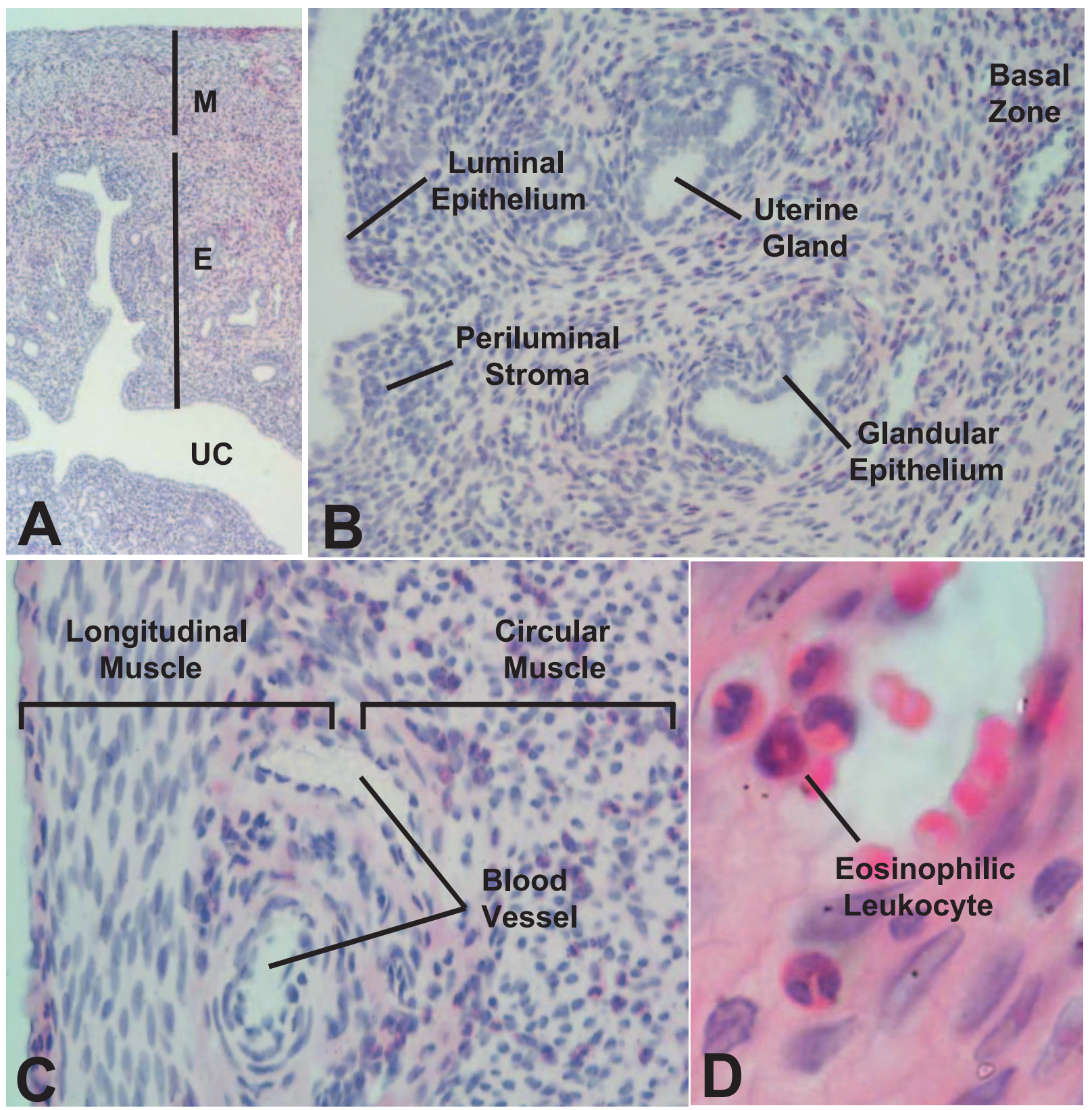

Figure 1 Photomicrographs of sections of the non-pregnant adult rat uterus stained with $\mathrm{H} \& \mathrm{E}$. (A) Longitudinal section showing myometrium (M), endometrium (E), and uterine cavity $(\mathrm{UC})$ at E0200 $\mathrm{h}(\times 4)$. (B) Higher magnification of $\mathrm{E}$ in panel $\mathrm{A}$; section through the endometrium showing the histology $(\times 10)$. (C) Higher power magnification of $M$ in panel $A$; section through the myometrium showing the histology $(\times 20)$. (D) Section showing uterine eosinophils at E1000 $\mathrm{h}(\times 40)$.

(accession number D49494) for BMP-3b (Takao et al. 1996); 737-757 and 1181-1200 (accession number Z22607) for BMP-4 (Chen et al. 1993); 6-25 and 475494 (accession number U66298) for BMP-6; 497-514 and 865-882 (accession number X56906) for BMP-7 (Ozkaynak et al. 1991); 441-460 and 876-895 (accession number D38082) for BMP-RIA (Takeda et al. 1994);
528-547 and 965-984 (accession number U89326) for BMP-RIB; 525-544 and 895-904 (accession number AF003942) for BMP-RII (Beppu et al. 1997); 94-113 and 404-423 (accession number U31203) for noggin (Valenzuela et al. 1995). These primers were selected from different exons of the corresponding genes to discriminate PCR products that might arise from possible chromosome 
Table 1 The adult non-pregnant rat uterus expresses mRNAs encoding the BMP family (ligands, receptors and binding proteins)

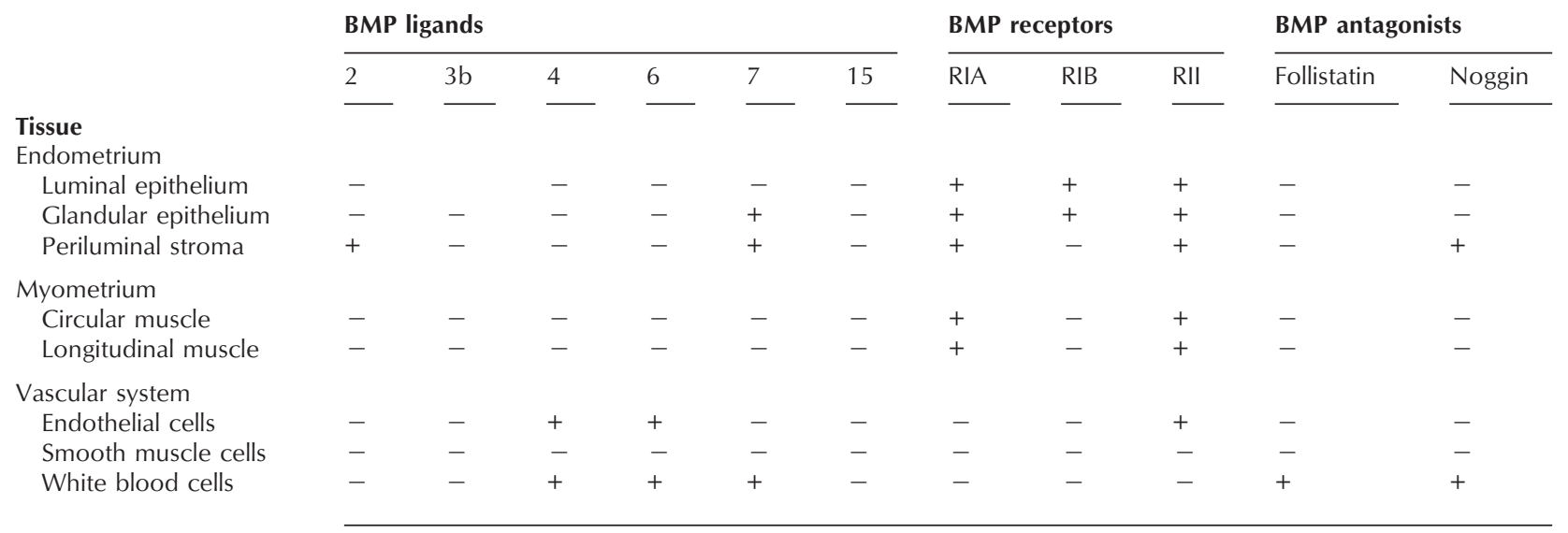

DNA contaminants. All PCR products were cloned into pBluescript SK + and their DNA sequences confirmed. The probe for follistatin was made from the rat follistatin cDNA clone as described previously (Shimasaki et al. 1989).

\section{Signal intensity}

The in situ hybridization experiments were performed twice for each BMP ligand, receptor and binding protein. The intensity of the hybridization signals was determined as previously reported (Erickson \& Shimasakki 2003). A subjective comparison of eight tissue sections per rat hybridized with the same concentrations of sense and antisense cRNAs and exposed for the same time (4 weeks) was made. The hybridization signal was estimated on a scale of $1+$ to $3+$ as originally described by Meunier et al. (1988): +, silver grains sparse, but positive hybridization; ++ , silver grains are numerous but do not cover the cell type in question; +++ , silver grains are very numerous and begin to merge in some places; $+/-$, there was heterogeneity in the hybridization signal, e.g. some of the histological units contained a signal, others did not; -, no detectable hybridization signal. In each experiment, tissues hybridized with the sense probe were used as the negative control. As a positive control, the specific hybridization of the antisense probes for BMP-2, $-3 b,-4,-6,-7,-15$, -RIA, -RIB, -RII, and follistatin was confirmed in adjacent ovary tissue in the same uterine tissue sections as described previously (Erickson \& Shimasaki 2003).

\section{Results}

\section{Histology of the adult rat uterus}

Figure 1 shows the histology of the normal adult rat uterus at estrus after staining with $\mathrm{H} \& \mathrm{E}$. It consists of an outer layer of smooth muscle cells, the myometrium, and an inner layer of glandular mucosa, the endometrium
(Fig. 1A). The endometrium consists of two epithelial cell types, the luminal epithelium and glandular epithelium (Fig. 1B). The luminal epithelium invaginates to form numerous tubular uterine glands that extend down into a relatively thick endometrial stroma (Fig. 1B). Juxtaposed to the luminal epithelium is a mass of densely packed cells termed the periluminal stroma or compact zone (Fig. 1B). It is rich in capillaries and undergoes growth and differentiation to form the decidual tissue of the maternal placenta (Abrahamsohn \& Zorn 1993). The stroma at the myometrium-endometrium junction, termed the basal zone, is characterized by the presence of uterine blood vessels (Fig. 1B). The myometrium consists of outer longitudinal and inner circular smooth muscle with a layer of loose connective tissue and blood vessels between (Fig. 1C). As with the basal zone (Fig. 1B), large numbers of eosinophilic leukocytes with typical ring-shaped nuclei (Tchernitchin 1973, Ross \& Klebanoft 1966) are commonly seen within the myometrium, particularly in the circular muscle layer (Fig. 1C and D).

\section{Expression of BMP family in uterine cells}

As seen in Table 1, the mRNAs encoding the BMP ligands (BMP-2, -4, -6 and -7), BMP receptors (BMPRIA, -RIB and -RII) and BMP antagonists (follistatin and noggin) were expressed in the rat uterus in a tissue-specific manner. In general, BMP-2, -4, -6, -7, BMP-RIB and follistatin mRNAs were particularly abundant, whereas the messages for BMP-RIA, RII and noggin appeared in lower amounts. No hybridization signals above background were detected for BMP-3b and -15 in the uterine specimens studied.

\section{BMP-2 mRNA expression}

BMP-2 mRNA is strongly expressed in the non-pregnant uterus, and over the cycle has a periluminal stroma- 
restricted expression pattern (Fig. 2A, B and C, and Table 1). The hybridization signal for BMP-2 showed a clear cyclic variation, being strong at diestrus II (DII1100 h, $+++)$ and proestrus (P1000 h, +++; P2000 h, +++), decreased at estrus $(\mathrm{E} 0200 \mathrm{~h},++$; E1000 h, +), and undetectable at diestrus DI (DI1100 h, -).

\section{BMP-4 mRNA expression}

BMP-4 mRNA was expressed in blood vessels and eosinophilic leukocytes (Fig. 2D to $\mathrm{H}$ and Table 1). In blood vessels, BMP-4 message was localized to the endothelial cells of large veins in the myometrium (Fig. 2F). BMP4-positive eosinophils were particularly abundant in the connective tissues near the endometrial-myometrial junction or basal zone (Fig. 2D, E, G and H). A positive BMP-4 hybridization signal is seen at all stages of the cycle, but appeared strongest at estrus $(\mathrm{E} 0200 \mathrm{~h},++$; $\mathrm{E} 1000 \mathrm{~h},++)$.

\section{BMP-6 mRNA expression}

The message encoding BMP-6 was expressed in the blood vessels (Table 1). It appeared restricted to the endothelial cells of small arteries located between the circular and longitudinal muscle layers of the myometrium (Fig. 3A, B and $\mathrm{C})$. The BMP-6 labeling intensity $(+++)$ of the endothelial cells appeared unchanged over the estrous cycle. Eosinophilic leukocytes showed a positive hybridization signal for BMP-6 on estrus (E0200 h and E1000 h), but the signal appeared weak and variable $(+/-)$.

\section{BMP-7 mRNA expression}

A strong hybridization signal for BMP-7 was observed in all uterine samples examined (Fig. 3D to $\mathrm{H}$ and Table 1). In the endometrium, BMP-7 mRNA was restricted to the periluminal stroma and glandular, epithelial cells (Fig. 3F, $\mathrm{G}$ and $\mathrm{H})$. There was no detectable change in the levels of BMP-7 expression $(+++)$ in the periluminal stroma and glandular epithelium over the estrous cycle. Eosinophilic leukocytes located within the basal zone appeared to display a weak signal $(+)$ for BMP-7 at estrus.

\section{BMP-RIA mRNA expression}

BMP-RIA mRNA appeared to be broadly expressed in the uterus (Table 1). In the myometrium, the signal was localized to the circular and longitudinal smooth muscle cells (Fig. 4A to D). In the endometrium, BMP-RIA was expressed in both the luminal and glandular epithelial cells (Fig. 4C, D and E). A weak hybridization signal for BMP-RIA appeared in the periluminal stroma (Fig. 4E). The levels of BMP-RIA mRNA expression appeared to change during the cycle, being abundant on proestrus (P1000 h, ++; P2000 h, ++), low on estrus (E0200 h,
$+/-; \mathrm{E} 1000 \mathrm{~h},+/-)$ and diestrus I $(+/-)$, and abundant on diestrus II $(++)$.

\section{$B M P-R I B m R N A$ expression}

BMP-RIB message was strongly expressed, being restricted to the luminal and glandular epithelial cells (Fig. 4F, G and $\mathrm{H}$, and Table 1). The level of expression of BMP-RIB showed a dynamic cyclic variation: it was highly expressed at diestrus I $(+++)$ and diestrus II $(+++)$, but appeared very low or undetectable at proestrus and estrus.

\section{BMP-RII $m R N A$ expression}

As with BMP-RIA, the message encoding BMP-RII appeared widely expressed throughout the uterus (Table 1). In the endometrium, the luminal and glandular epithelial cells exhibited a moderate hybridization signal (Fig. 4I, J and K), with a weaker signal appearing in the periluminal stroma (Fig. 4K). In the myometrium, the circular and longitudinal smooth muscle cells showed a positive, albeit weak, hybridization signal (Fig. 4I and J), as did some vascular endothelial cells. The expression of BMP-RII mRNA appeared cyclical; the signal was moderate at proestrus $(\mathrm{P} 1000 \mathrm{~h},++$; $\mathrm{P} 2000 \mathrm{~h},++)$ and very low or undetectable at other stages of the cycle.

\section{Noggin $m R N A$ expression}

Noggin mRNA was detected in the periluminal stroma (Fig. 5A, B and C, and Table 1). Noggin mRNA in the periluminal stroma was detected only at diestrus II $1100 \mathrm{~h}$. The eosinophils at estrus also appeared to show a positive, albeit weak, hybridization signal for noggin (Table 1).

\section{Follistatin mRNA expression}

In a previous study using solution hybridization-RNAase protein assay, Mercado et al. (1993) found high levels of follistatin mRNA in the non-pregnant rat uterus at estrus; however, the cellular site of expression was not identified. Here, we find that follistatin mRNA expression was restricted to the eosinophilic leukocytes, located in the endometrium and the interstitial tissue of the myometrium (Fig. 5D, E and F, and Table 1). Over the cycle a positive hybridization signal for follistatin was evident at estrus (E0200 h, +++; E1000 h, ++). Because follistatin mRNA was detected only in eosinophils, the abundance of follistatin message in the uterus appears tightly correlated with the number of eosinophils present in the uterine stroma during the cycle.

\section{Discussion}

This study shows that the endometrial cycle in the non-pregnant rat uterus involves a precise spatial and 

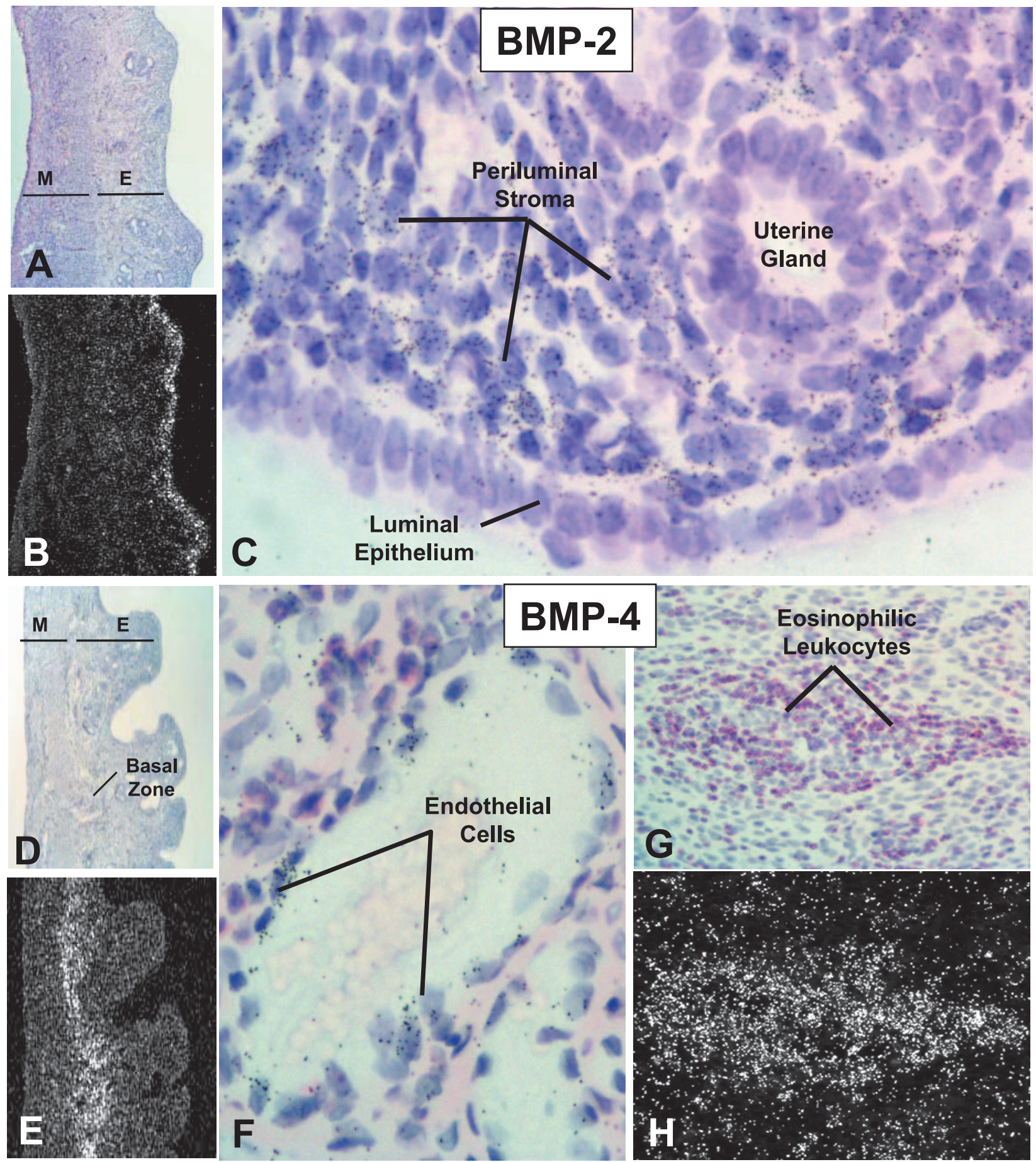

Figure 2 In situ hybridization of BMP-2 and -4 mRNAs in the non-pregnant rat uterus. Dark-field (B, E and H) and bright-field (A, D and G) micrographs of the same sections of uterus. $M$, myometrium; $E$, endometrium. Magnifications are: panels $A, B, D$ and $E, \times 4 ; G$ and $\mathrm{H}, \times 20 ; \mathrm{C}$ and $\mathrm{F}, \times 40$. Panels A to E stained with hematoxylin; panels $\mathrm{F}, \mathrm{G}$ and $\mathrm{H}$ stained with H\&E. Using dark-field and bright-field optics, white and black dots respectively represent silver grains. (A, B and C) Note BMP-2 hybridization in the periluminal stroma of the endometrium; DII1100 h. (D to H) Note BMP-4 hybridization signal in endothelial cells and eosinophilic leukocytes; E0200 h. 

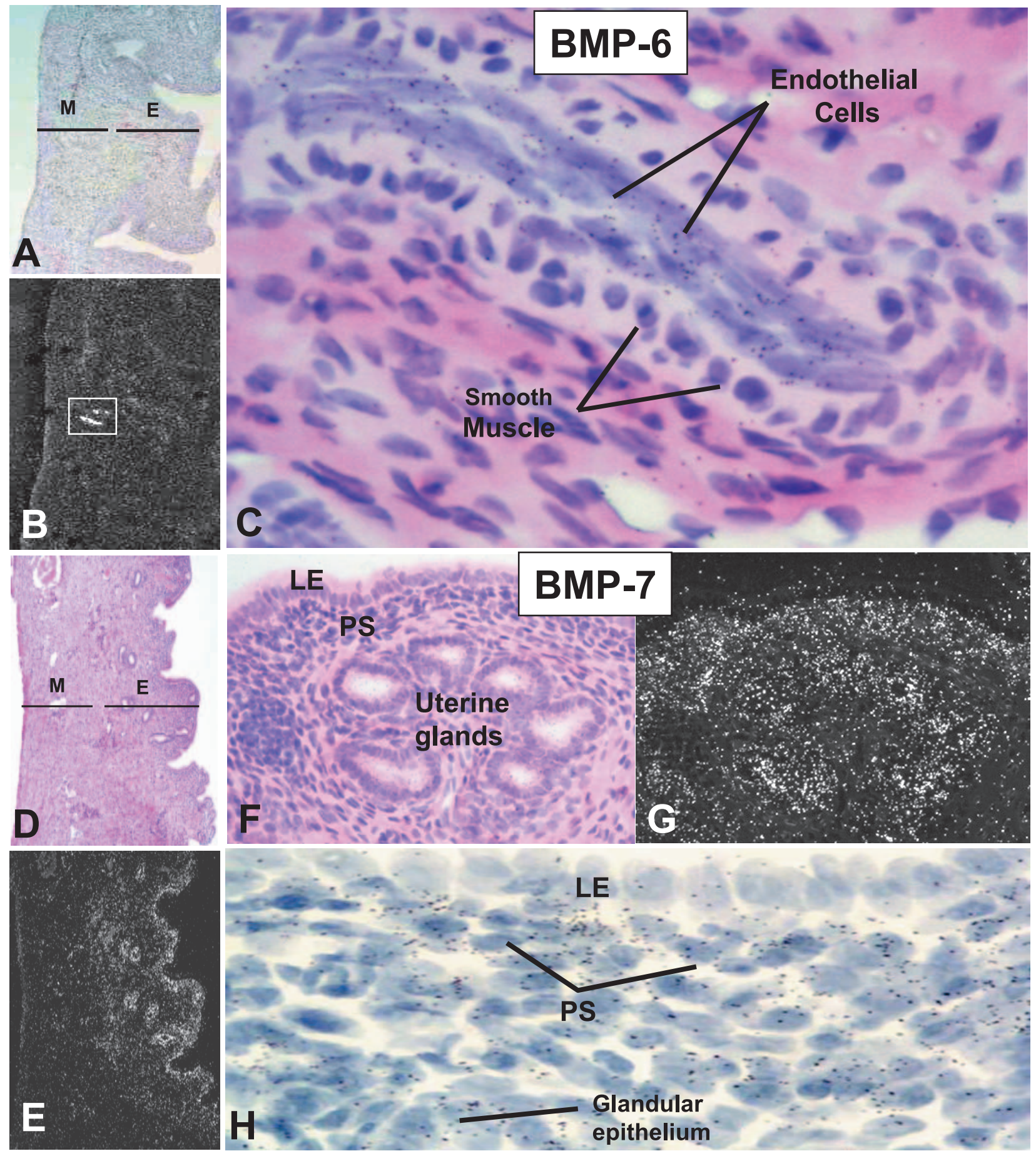

Figure 3 In situ hybridization of BMP-6 and -7 mRNAs in non-pregnant rat uterus. Dark- field (B, E and G) and bright-field (A, D and F) micrographs of the same sections of uterus. Magnifications: panels $A, B, D$ and $E, \times 4$; panels $F$ and $G, \times 20 ;$ panels $C$ and $H \times 40$. Panels A to G stained with H\&E; panel H stained with hematoxylin. (A, B and C) Note BMP-6 (boxed in, panel B) is selectively expressed in endothelial cells of small arteries in the myometrium; E0200 h. (D to H) Note BMP-7 hybridization signal in periluminal stroma (PS) and glandular epithelial cells (GE); P2000 h. 


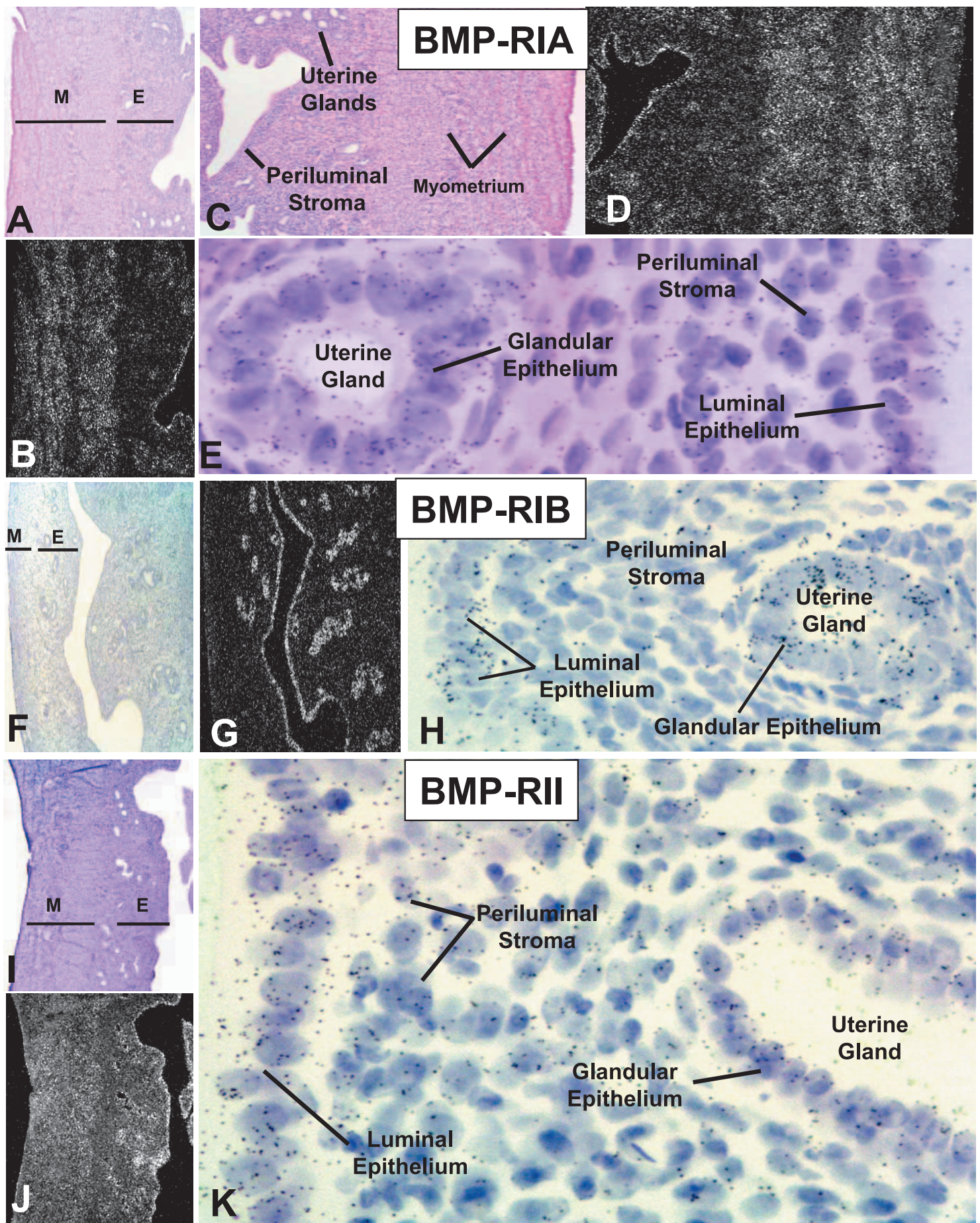

Figure 4 In situ hybridization of BMP receptor mRNAs in the non-pregnant uterus. Dark-field (B, D, G and J) and bright-field ( $A, C, F$ and $I$ ) micrographs of same sections of uterus ( $M$, myometrium; $E$, endometrium). Magnifications: panels $\mathrm{A}, \mathrm{B}, \mathrm{E}, \mathrm{G}, \mathrm{I}$ and $\mathrm{J}, \times 4$; panels $\mathrm{C}$ and $\mathrm{D}, \times 10$; panels $\mathrm{E}, \mathrm{H}$ and $\mathrm{K}, \times 40$. Panels $\mathrm{A}, \mathrm{B}, \mathrm{C}, \mathrm{D}, \mathrm{E}, \mathrm{I}$ and $\mathrm{J}$ stained with $\mathrm{H} \& \mathrm{E}$; panels F, G, H and K stained with hematoxylin. (A to E) Note the expression of BMP-RIA in the myometrium (circular and longitudinal muscle) and the endometrium (periluminal stroma and epithelial cells; P2000 h. (F, G and H) Note the selective expression of BMP-RIB in endometrial luminal and glandular epithelium; DII1100 h. (I, J and K) Note BMP-RII hybridization in endometrial luminal and glandular epithelium and weaker hybridization in myometrium and periluminal stroma; P2000 h. 


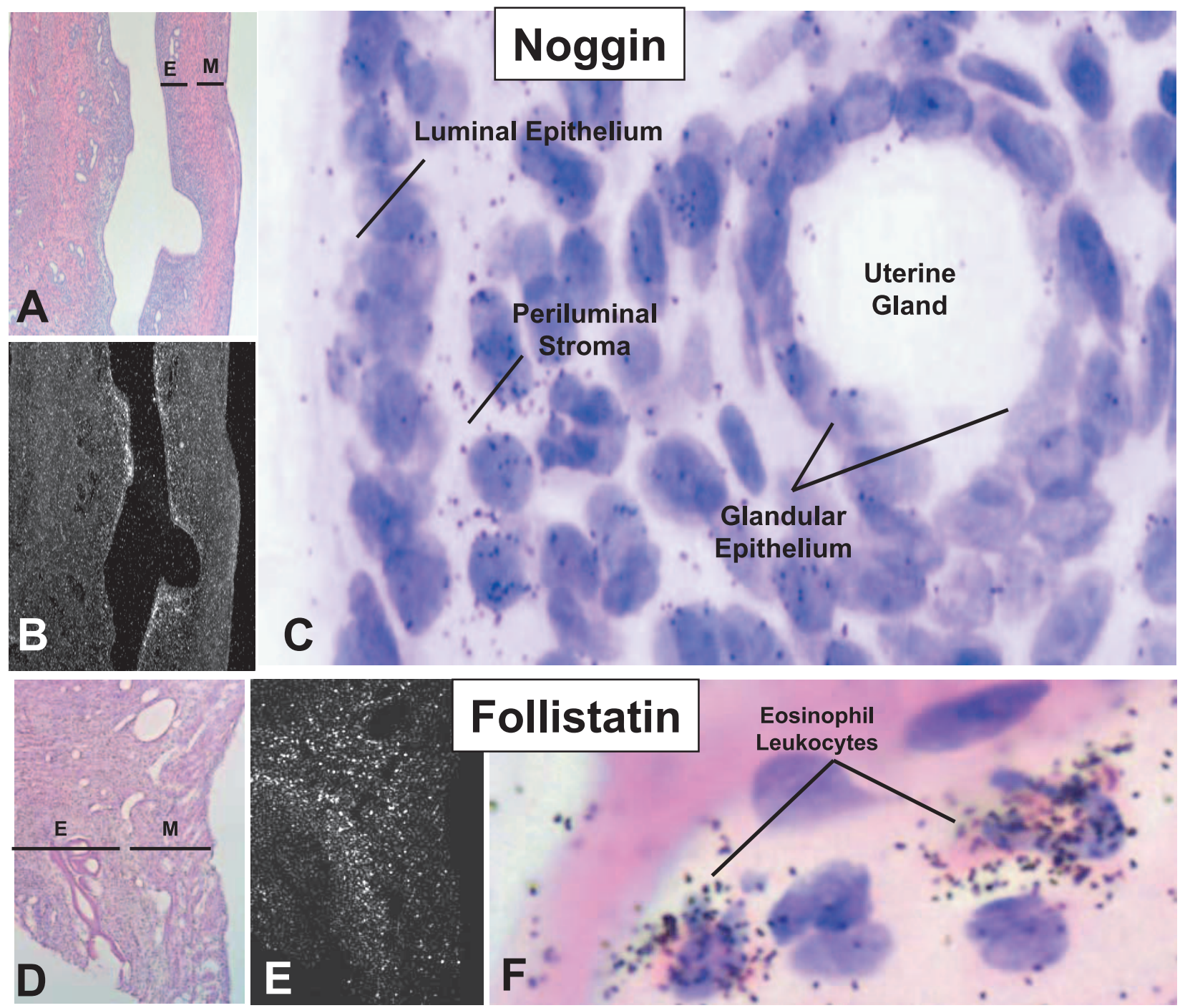

Figure 5 In situ hybridization of noggin and follistatin mRNAs in the adult rat uterus. Dark-field (B and E) and bright-field (A and D) micrographs $(\times 4)$ of the same uterus sections $(M$, myometrium; $E$, endometrium). All sections stained with H\&E. Higher magnification bright-field micrographs: panel $\mathrm{C}, \times 40 ; \mathrm{F}, \times 100$. (A, B and C) Note noggin signal in the periluminal stroma; DII1100 h. (D, E and F) Note follistatin hybridization to eosinophilic leukocytes; E0200 h.

temporal pattern of expression of the genes encoding BMP receptors, BMP ligands and BMP antagonists. Thus, the regulated expression of BMPs might add another mechanism by which cell-specific modulation can occur during the uterine/endometrial cycle. The data are as yet too preliminary to know what cellular effects the BMPs might regulate. However, inasmuch as BMPs have important functions in controlling proliferation, differentiation and apoptosis in other reproductive tissues (Shimasaki et al. 2004), it is not unreasonable to assume that uterine BMP actions could play a role in the mechanisms governing tissue remodeling during the endometrial cycle. It is important to acknowledge that the interpretation of our studies are limited by the fact that thus far, there is no evidence that the BMP mRNAs are translated into functional proteins. In this context, it should be kept in mind that: (1) translation may take time and therefore drawing conclusions about the stages of the cycle at which BMPs act cannot be assumed from the mRNA levels alone; (2) the sites of action of ligands may differ from sites of synthesis.

Our results indicate that the genes encoding cell surface $\mathrm{BMP}$ receptors are expressed in the non-pregnant uterus. The mRNAs encoding BMP-RIA, -RIB and -RII are found in the epithelium and BMP-RIA and -RII are found in the periluminal stroma and myometrium. These 
observations suggest that both the endometrium and myometrium are targets for BMP signaling. The further observation that the levels of BMP receptor expression appear to change during the cycle raises the possibility that the control of receptor gene expression may play a role in governing the level of BMP signaling in uterine target cells. In support of this possibility, deletion of BMPrIB in mice severely disrupts uterine structure such that the endometrial lining is thin, the epithelial cells remain undifferentiated and there are few if any uterine glands (Yi et al. 2001). This study provides clear support for a causal role of BMP-RIB in uterine gland morphogenesis. Our studies demonstrate that BMP-RIB mRNA is expressed exclusively in the luminal and glandular epithelial cells, and only during the secretory (luteal) phase of the cycle, i.e. at diestrus I and II. Collectively, these lines of evidence argue for a model in which the expression of BMP-RIB in the epithelial cells at diestrus I and II plays a causative role in promoting the growth and development of uterine glands. It will be important to determine the mechanism by which BMP-RIB promotes uterine gland development. In this light, it is notable that the luminal and glandular epithelial cells show maximal mitosis at diestrus (Bertalanffy \& Lau 1963, Burroughs et al. 2000, MendozaRodríguez et al. 2003). Thus, the concept that the regulated expression of BMP-RIB might be involved in controlling epithelial cell proliferation seems to be a good working hypothesis. In this hypothesis, it will be interesting to consider whether the intense expression of PR in the epithelial cells during diestrus (Ohta et al. 1993) has a role in the regulation of epithelial BMP-RIB gene expression.

During the cycle, we found that the messages encoding BMP-2 and -7 are highly expressed in the endometrium of the non-pregnant rat uterus. That is, BMP-2 and -7 are expressed in the periluminal stroma and BMP-7 in the glandular epithelium. Therefore, any model of BMP receptor signaling in the uterus must take into account the regulation of BMP-2 and -7 expression in the endometrium. Classic mesenchymal-epithelial BMP pathways have been shown to direct a variety of developmental phenomena (Hogan 1996, 1999). Our observation that the periluminal stroma expresses BMP-2 and -7 and the epithelium expresses BMP-RIA, -RIB and -RII, fits with a classic mesenchymal-epithelial BMP pathway. In this BMP-2/BMP-7 model, Cooke et al. (1997) made the interesting finding that estrogen-stimulated mitosis in the uterine epithelium is a paracrine event mediated by ER $\alpha$ in the periluminal stroma. Further studies are required to test the intriguing hypothesis that stroma-derived BMP-2 and/or -7 may be paracrine factors that mediate estrogendependent epithelial mitosis in the mammalian uterus. It is known that secretions by the uterine glands are required for uterine receptivity and implantation in rodents (Gray et al. 2001). Hence, the question: Could endometrialderived BMP-2 and -7 play a role in this important process? Finally, it is notable that the periluminal stroma in the non-pregnant rat uterus expresses noggin message at DII. This finding confirms and extends studies in pregnant mice showing noggin expression in endometrial stroma cells during implantation (Paria et al. 2001). Noggin binds several BMPs (including BMP-2 and -7) with very high (picomolar) affinities, and by binding tightly to BMPs, noggin prevents BMPs from interacting with their receptors (Zimmerman et al. 1996). We suggest, therefore, that if noggin is secreted from the periluminal stroma at DII it could antagonize BMP-2 and -7 signaling.

Interestingly, the level of BMP-2 mRNA expression undergoes dynamic changes over the estrous cycle. That is, BMP-2 mRNA is expressed at relatively high levels throughout the cycle, except at E1000 h and DI when the message appears to be very low or undetectable. This result could be interpreted to mean that uterine BMP-2 gene expression (like that of BMP-RIB) is tightly regulated and thus of physiological importance. An important question concerns the nature of the regulation of BMP-2 expression in the endometrium and its physiological function. In the case of regulation, it is noteworthy that the time at which BMP-2 mRNA is expressed at low levels coincides with luteinization (Butcher et al. 1974). Thus, it is possible that progesterone secreted by the corpus luteum of the cycle could act to inhibit BMP-2 expression in the periluminal stroma. Consistent with this idea is the expression of $\mathrm{PR}$ in the periluminal stroma (Ohta et al. 1993). In the case of function, it is notable that DII is characterized by the highest rates of apoptosis in the endometrial epithelial cells (Spornitz et al. 1994, Burroughs et al. 2000, Mendoza-Rodríguez et al. 2003). This, coupled with the ability of BMP-2 to cause apoptosis in target cells (Macias et al. 1997, Song et al. 1998, Kimura et al. 2000, Hay et al. 2001, Kawamura et al. 2002), raises the possibility that the temporal pattern of BMP-2 expression could have a role in the regulation of epithelial apoptosis/proliferation during the cycle.

In contrast to BMP-2, we found no evidence that the levels of endometrial BMP-7 mRNA change over the cycle. Thus, the concept that the periluminal stroma and glandular epithelial cells constitutively express high levels of BMP-7 during the endometrial cycle is supported by our results. In a previous paper, Ozkaynak et al. (1997) reported that administration of exogenous estradiol markedly inhibits uterine BMP-7 transcripts in vivo. Similarly, studies on the chick oviduct have demonstrated an inhibitory effect of estrogen on BMP-7 gene expression (Monroe et al. 2000). Therefore, our finding that BMP-7 expression was not suppressed by increases in circulating estradiol levels during the estrous cycle was unexpected. The reason for this apparent discrepancy is not known; however, it may involve the pituitary. In Ozkaynak's study, normal non-pregnant adult mice (with pituitary) were injected for 4 days with increasing doses of estradiol. In the oviduct experiments intact chickens were implanted with 


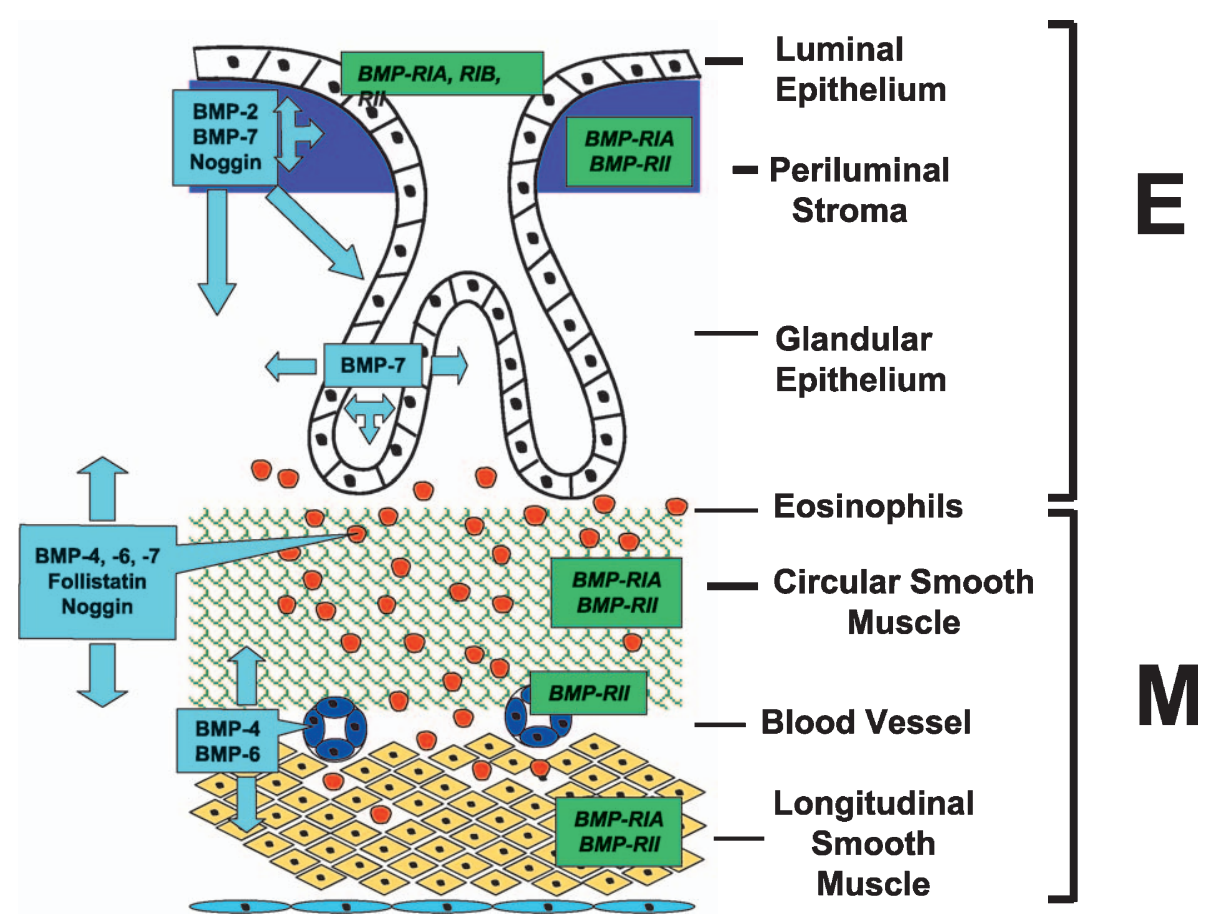

Figure 6 Schematic model showing the existence of a BMP system in the non-pregnant rat uterus, complete with ligands, receptors and antagonists. In the endometrium (E), endogenously produced BMP-2 and -7 could act as ligands for the BMP receptors (BMP-RIA, -RIB and -RII) expressed in the periluminal stroma and epithelial cells. Such BMP signaling pathways may directly influence physiological responses during the endometrial cycle by autocrine and paracrine mechanisms (arrows). In the myometrium, BMPs produced by vascular endothelial cells and eosinophils may participate directly in the control of smooth muscle and blood vessel activities by receptor-mediated signaling. Presumably, eosinophil-derived noggin and follistatin could be modulators of BMP-receptor-dependent responses.

diethylstilbestrol (DES) pellets for at least 2 weeks. While it is clear the exogenous estrogen will directly stimulate cellular responses in the uterus and oviducts, it will also initiate responses in other target tissues, including the pituitary. Consistent with a role of the pituitary, we have observed that hypophysectomy results in the loss of BMP-7 message in the rat uterus (Erickson, unpublished observations). This evidence suggests that the estrogeninduced down-regulation of uterine BMP-7 message may be a secondary response to estrogen-induced changes in pituitary hormones, such as elevated prolactin secretion. That prolactin receptors are expressed in the endometrium (Bole-Feysot et al. 1998) could be regarded as general support for this pituitary/prolactin hypothesis.

The concept of tissue-specific expression of BMPs in the uterine vasculature is supported by our findings that BMP-4, -6 and -RII mRNAs appear to be constitutively expressed in the vascular endothelial cells. This concept is further supported by the expression of BMP-4 and Smad1 in vascular endothelial cells of the pregnant mouse uterus (Ying \& Zhao 2000). Two of the most striking features of the vascular BMPs in the non-pregnant uterus are that:
(1) they appear restricted to blood vessels in the myometrium; (2) BMP-4 and -6 show very different patterns of expression, being located in endothelial cells of veins and arteries respectively. Consequently, to understand the potential for cellular functions of the BMPs in the uterine vasculature, one must consider this spatial pattern of BMP-4 and -6 expression within the myometrial endothelial cells. In this concept, it should be pointed out that estrogen plays a major role in remodeling the vasculature of the rodent uterus (Clark et al. 1977, Couse \& Korach 1999, Celia \& Osol 2002, Page et al. 2002), perhaps by activating ER $\alpha$ expressed in the endothelial cells (Andersson et al. 2001). The degree to which the endothelial-derived BMPs might contribute to the estrogen-dependent structural remodeling of the uterine vasculature remains to be determined. It is noteworthy that BMP-6 knockout mice have normal sized litters (Solloway et al. 1998). This result could imply that BMP-6 expressed by endothelial cells of small myometrial arteries is not essential for uterine vascular remodeling in the rat.

Regarding blood cells, our study indicates that uterine eosinophils express BMP antagonists (follistatin and noggin 
mRNAs) and BMP ligands (BMP- 4, -6 and -7 mRNAs) at estrus. An interesting question is whether the expression of BMPs in eosinophils is applicable to uterine homeostasis. It has been known for many years that the uterine cycle involves the recruitment and infiltration of large numbers of circulating eosinophils into the perivascular uterine stoma at estrus (Rytomaa 1960). During estrus, the uterine eosinophils undergo lysis and release their contents into the interstitial spaces (Ross \& Klebanoff 1966, Kelenyi \& Nemeth 1972). This process is associated with marked uterine edema. The importance of estrogen in provoking eosinophil chemotaxis into the uterus is clear (Tchernitchin et al. 1974); however, the cellular mechanisms and the functions of this uterine phenomenon remain poorly understood. Two molecules required for estrogen-dependent chemotaxis of eosinophils into the uterine stroma are interleukin-5 (IL-5; Perez et al. 1996) and eotaxin (Gouon-Evans \& Pollard 2001). In IL-5- and eotaxin-deficient females, the virtual absence of eosinophils has little or no effect on structure-function relationships in the uterus. Indeed, in eotaxin-deficient females, the estrous cycles and reproductive functions are normal (Gouon-Evans \& Pollard 2001). Thus, the increase in eosinophils at estrus does not appear to play a critical role in establishing uterine homeostasis. Nonetheless BMP-2 (Kim et al. 1999, Willette et al. 1999), BMP-4 (Cunningham et al. 1992, Miyazaki et al. 2003) and BMP-7 (Gould et al. 2002, Lee et al. 2003) have been linked to chemotaxis in a variety of cell types (including blood cells), leaving open the question of whether BMPs (in addition to IL-5 and eotaxin), might also play a role in eosinophil infiltration into the uterus. By in situ hybridization, we detected BMP-RIA and -RII in the myometrium. It will be interesting to learn whether eosinophil-derived BMPs might affect the circular and smooth muscle cells, perhaps contributing to the known activation of apoptosis in these cells at estrus (Burroughs et al. 2000).

In conclusion, the general principle to emerge from this work (Fig. 6) is that the normal endometrial/uterine cycle is accompanied by the spatiotemporal pattern of expression of at least nine BMP genes, which fit into three functional classes: ligands (BMP-2, $-4,-6$ and -7 ), receptors (BMPRIA, -IB and -II) and antagonists (follistatin and noggin). Given the fact that these BMPs can control mitosis, differentiation and apoptosis, the findings presented here may have new implications for understanding uterine growth, glandular morphogenesis, vascular remodeling and cell fate specification. Further studies should build on our finding by exploring both the regulation of tissuespecific BMP gene expression in the uterus and the functional consequences of their expression. It should be apparent that understanding BMP responses in the uterus could have potential relevance in the area of infertility and pathology, including endometriosis, leiomyomas and endometrial cancer.

\section{Acknowledgements}

We thank Andi Hartgrove for preparing the manuscript and for her work on the Figures.

\section{Funding}

This work was supported by NIH U54 HD12303 as part of the Specialized Cooperative Centers Program in Reproduction Research.

\section{References}

Abrahamsohn PA \& Zorn TMT 1993 Implantation and decidualization in rodents. Journal of Experimental Zoology 266 603-628.

Andersson C, Lydrup M-L, Fernö M, Idvall I, Gustafsson JA \& Nilsson B-O 2001 Immunocytochemical demonstration of oestrogen receptor $\mathrm{b}$ in blood vessels of the female rat. Journal of Endocrinology 169 241-247.

Arnett-Mansfield RL, deFazio A, Mote PA \& Clarke CL 2004 Subnuclear distribution of progesterone receptors A and B in normal and malignant endometrium. Journal of Clinical Endocrinology and Metabolism 89 1429-1442.

Balemans W \& Van Hul W 2002 Extracellular regulation of BMP signaling in vertebrates: A cocktail of modulators. Developmental Biology 250 231-250.

Beppu H, Minowa O, Miyazono K \& Kawabata M 1997 cDNA cloning and genomic organization of the mouse BMP type II receptor. Biochemical and Biophysical Research Communications 235 499-504.

Bertalanffy FD \& Lau C 1963 Mitotic rates, renewal times, and cytodynamics of the female genital tract epithelia in the rat. Acta Anatomica 54 39-81.

Bole-Feysot C, Goffin V, Edery M, Binart N \& Kelly PA 1998 Prolactin (PRL) and its receptor: actions, signal transduction pathways and phenotypes observed in PRL receptor knockout mice. Endocrine Reviews 19 225-268.

Botchkarev VA 2003 Bone morphogenetic proteins and their antagonists in skin and hair follicle biology. Journal of Investigative Dermatology 120 36-47.

Burroughs KD, Fuchs-Young R, Davis B \& Walkera CL 2000 Altered hormonal responsiveness of proliferation and apoptosis during myometrial maturation and the development of uterine leiomyomas in the rat. Biology of Reproduction $631322-1330$.

Butcher RL, Collins WE \& Fugo NW 1974 Plasma concentration of LH, FSH, prolactin, progesterone and estradiol-17 beta throughout the 4-day estrous cycle of the rat. Endocrinology 94 1704-1708.

Canalis E, Economides AN \& Gazzerro E 2003 Bone morphogenetic proteins, their antagonists, and the skeleton. Endocrine 24 218-235.

Celia G \& Osol G 2002 Venoarterial communication as a mechanism for localized signaling in the rat uterine circulation. American Journal of Obstetrics and Gynecology 187 1653-1659.

Chen D, Feng JQ, Feng M, Harris MA, Mundy GR \& Harris SE 1993 Cloning and sequence of bone morphogenetic protein 4 cDNA from fetal rat calvarial cell. Biochimica et Biophysica Acta 1174 289-292.

Clark KE, Farley DB, Van Orden DE \& Brody MJ 1977 Estrogen-induced uterine hyperemia and edema persist during histamine receptor blockade. Proceedings of the Society for Experimental Biology and Medicine 156 411-416.

Conneely OM, Mulac-Jericevic B, DeMayo F, Lydon JP \& O'Malley BW 2002 Reproductive functions of progesterone receptors. Recent Progress in Hormone Research 57 339-355. 
Cooke PS, Buchanan DL, Young P, Setiawan T, Brody J, Korach KS, Taylor J, Lubahn DB \& Cunha GR 1997 Stromal estrogen receptors mediate mitogenic effects of estradiol on uterine epithelium. PNAS 94 6535-6540.

Couse JF \& Korach KS 1999 Estrogen receptor null mice: what have we learned and where will they lead us? Endocrine Reviews 20 $358-417$.

Cunningham NS, Paralkar V \& Reddi AH 1992 Osteogenin and recombinant bone morphogenetic protein $2 \mathrm{~B}$ are chemotactic for human monocytes and stimulate transforming growth factor $\beta 1$ mRNA expression. PNAS 89 11740-11744.

Curtis SW, Washburn T, Sewall C, DiAugustine R, Lindzey J, Couse JF \& Korach KS 1996 Physiological coupling of growth factor and steroid receptor signaling pathways: estrogen receptor knockout mice lack estrogen-like response to epidermal growth factor. PNAS 93 12626-12630

Curtis SW, Clark J, Myers P \& Korach KS 1999 Disruption of estrogen signaling does not prevent progesterone action in the estrogen receptor of a knockout mouse uterus. PNAS 96 $3646-3651$

Dong J, Albertini DF, Nishimori K, Kumar TR, Lu N \& Matzuk M 1996 Growth differentiation factor-9 is required during early ovarian folliculogenesis. Nature 383 531-535.

Erickson GF \& Shimasaki S 2003 The spatiotemporal expression pattern of the bone morphogenetic protein family in rat ovary cell types during the estrous cycle. Reproductive Biology and Endocrinology 19.

Galloway SM, McNatty KP, Cambridge LM, Laitinen MPE, Juengel JL, Jokiranta TS, McLaren RJ, Luiro K, Dodds KG, Montgomery GW et al. 2000 Mutations in an oocyte-derived growth factor gene (BMP15) cause increased ovulation rate and infertility in a dosage-sensitive manner. Nature Genetics 25 279-283.

Giudice LC, Mark SP \& Irwin JC 1998 Paracrine actions of insulin-like growth factors and IGF binding protein-1 in non-pregnant human endometrium and at the decidual-trophoblast interface. Journal of Reproductive Immunology 39 133-148.

Godkin JD \& Dore JJ 1998 Transforming growth factor beta and the endometrium. Reviews of Reproduction 3 1-6.

Gould SE, Day M, Jones SS \& Dorai H 2002 BMP-7 regulates chemokine, cytokine, and hemodynamic gene expression in proximal tubule cells. Kidney International 61 51-60.

Gouon-Evans V \& Pollard JW 2001 Eotaxin is required for eosinophil homing into the stroma of the pubertal and cycling uterus. Endocrinology 142 4515-4521.

Graham JD \& Clarke CL 1997 Physiological action of progesterone in target tissues. Endocrine Reviews 18 502-519.

Gray CA, Bartol FF, Tarleton BJ, Wiley AA, Johnson GA, Bazer FW \& Spencera TE 2001 Developmental biology of uterine glands. Biology of Reproduction 65 1311-1323.

Guo Q, Kumar TR, Woodruff T, Hadsell LA, DeMayo FJ \& Matzuk MM 1998 Overexpression of mouse follistatin causes reproductive defects in transgenic mice. Molecular Endocrinology 12 96-106.

Hay E, Lemonnier J, Fromigue O \& Marie PJ 2001 Bone morphogenetic protein-2 promotes osteoblast apoptosis through a Smad-independent, protein kinase C-dependent signaling pathway. Journal of Biological Chemistry $27629028-29036$.

Hodges LC, Houston KD, Hunter DS, Fuchs-Young R, Zhang Z, Wineker RC \& Walker CL 2002 Transdominant suppression of estrogen receptor signaling by progesterone receptor ligands in uterine leiomyoma cells. Molecular and Cellular Endocrinology 196 $11-20$.

Hogan BL 1996 Bone morphogenetic proteins: multifunctional regulators of vertebrate development. Genes and Development 10 1580-1594.

Hogan BL 1999 Morphogenesis. Cell 96 225-233.

Ingman WV \& Robertson SA 2002 Defining the actions of transforming growth factor beta in reproduction. Bioessays 24 904-914.
Jones RL, Salamonsen LA \& Findlay JK 2002 Potential roles for endometrial inhibins, activins and follistatin during human embryo implantation and early pregnancy. Trends in Endocrinology and Metabolism 13 144-150.

Kaiser M, Gibori G \& Mayo KE 1990 The rat follistatin gene is highly expressed in decidual tissue. Endocrinology 126 2768-2770.

Katsuda SI, Yoshida M, Watanabe T, Kuroda H, Ando-Lu J, Takahashi M, Hayashi H \& Maekawa A 1999 Estrogen receptor mRNA in uteri of normal estrous cycling and ovariectomized rats by in situ hybridization. Proceedings of the Society for Experimental Biology and Medicine 221 207-214.

Kawamura C, Kizaki M \& Ikeda Y 2002 Bone morphogenetic protein (BMP)-2 induces apoptosis in human myeloma cells. Leukemia and Lymphoma 43 635-639.

Kelenyi G \& Nemeth A 1972 Tissue eosinophil leucocytes. II. Electron microscopy and histochemistry of the uterine eosinophil leucocytes in oestrogen-treated spayed rats. Acta Biologica Academiae Scientiarum Hungaricue 23 253-267.

Kim WJ, Mohan RR \& Wilson SE 1999 Effect of PDGF, IL-1 alpha, and BMP2/4 on corneal fibroblast chemotaxis: expression of the platelet-derived growth factor system in the cornea. Investigative Ophthalmology and Visual Science 40 1364-1372.

Kimura N, Matsuo R, Shibuya H, Nakashima K \& Taga T 2000 BMP2-induced apoptosis is mediated by activation of the TAK1-p38 kinase pathway that is negatively regulated by Smad6. Journal of Biological Chemistry 275 17647-17652.

Kurita T, Lee K-J, Cooke PS, Lydon JP \& Cunha GR 2000 Paracrine regulation of epithelial progesterone receptor and lactoferrin by progesterone in the mouse uterus. Biology of Reproduction $\mathbf{6 2}$ 831-838.

Lee M-J, Yang CW, Jin DC, Chang YS, Bang BK \& Kim Y-S 2003 Bone morphogenetic protein-7 inhibits constitutive and interleukin- $1 \beta$-induced monocyte chemoattractant protein-1 expression in human mesangial cells: Role for JNK/AP-1 pathway. Journal of Immunology 170 2557-2563.

Lubahn DB, Moyer JS, Golding TS, Couse JF, Korach KS \& Smithies O 1993 Alteration of reproductive function but not prenatal sexual development after insertional disruption of the mouse estrogen receptor gene. PNAS 90 11162-11166.

Lydon JP, DeMayo FJ, Funk CR, Mani SK, Hughes AR, Montgomery CA Jr, Shyamala G, Conneely OM \& O'Malley BW 1995 Mice lacking progesterone receptor exhibit pleiotropic reproductive abnormalities. Genes and Development 9 2266-2278.

Macias D, Ganan Y, Sampath T, Piedra M, Ros M \& Hurle J 1997 Role of BMP-2 and OP-1 (BMP-7) in programmed cell death and skeletogenesis during chick limb development. Development 124 1109-1117.

Mendoza-Rodríguez CA, Merchant-Larios H, Segura-Valdez ML, Moreno-Mendoza N, Cruz ME, Arteaga-López P, Camacho-Arroyo I, Domínguez R \& Cerbón M 2003 c-fos and estrogen receptor gene expression pattern in the rat uterine epithelium during the estrous cycle. Molecular Reproduction and Development 64 379-388.

Mercado M, Shimasaki S, Ling N \& DePaolo L 1993 Effects of estrous cycle stage and pregnancy on follistatin gene expression and immunoreactivity in rat reproductive tissues: progesterone is implicated in regulating uterine gene expression. Endocrinology 132 1774-1781.

Mertens HJMM, Heineman MJ, Theunissen PHMH, de Jong FH \& Evers JLH 2001 Androgen, estrogen and progesterone receptor expression in the human uterus during the menstrual cycle. European Journal of Obstetrics and Gynecology and Reproductive Biology $9858-65$.

Meunier H, Cajander SB, Roberts VJ, Rivier C, Sawchenko PE, Hsueh AJW \& Vale W 1988 Rapid changes in the expression of inhibin $\alpha_{-}, \beta \mathrm{A}_{-}$, and $\beta \mathrm{B}$-subunits in ovarian cell types during the rat estrous cycle. Molecular Endocrinology 2 1352-1363. 
Miyazaki Y, Oshima K, Fogo A \& Ichikawa I 2003 Evidence that bone morphogenetic protein 4 has multiple biological functions during kidney and urinary tract development. Kidney International 63 835-844.

Monroe DG, Jin DF \& Sanders MM 2000 Estrogen opposes the apoptotic effects of bone morphogenetic protein 7 on tissue remodeling. Molecular and Cellular Biology 20 4626-4634.

Mote PA, Balleine RL, McGowan EM \& Clarke CL 1999 Colocalization of progesterone receptors $\mathrm{A}$ and $\mathrm{B}$ by dual immunofluorescent histochemistry in human endometrium during the menstrual cycle. Journal of Clinical Endocrinology and Metabolism $842963-2971$.

Mulsant P, Lecerf F, Fabre S, Schibler L, Monget P, Lanneluc I, Pisselet C, Riquet J, Monniaux D, Callebaut I et al. 2001 Mutation in bone morphogenetic protein receptor-IB is associated with increased ovulation rate in Booroola Merino ewes. PNAS 98 5104-5109.

Nelson K, Takahashi T, Lee D, Luetteke N, Bossert N, Ross K, Eitzman B \& McLachlan J 1992 Transforming growth factor-alpha is a potential mediator of estrogen action in the mouse uterus. Endocrinology 131 1657-1664.

Ohta Y, Sato T \& Iguchi T 1993 Immunocytochemical localization of progesterone receptor in the reproductive tract of adult female rats. Biology of Reproduction 48 205-213.

Ozkaynak E, Schnegelsberg PN \& Oppermann H 1991 Murine osteogenic protein (OP-1): high levels of mRNA in kidney. Biochemical and Biophysical Research Communications 179 116-123.

Ozkaynak E, Jin DF, Jelic M, Vukicevic S \& Oppermann H 1997 Osteogenic protein-1 mRNA in the uterine endometrium. Biochemical and Biophysical Research Communications 234 242-246.

Page KL, Celia G, Leddy G, Taatjes DJ \& Osol G 2002 Structural remodeling of rat uterine veins in pregnancy. American Journal of Obstetrics and Gynecology 187 1647-1652.

Paria BC, Ma W-G, Tan J, Raja S, Das SK, Dey SK \& Hogan BLM 2001 Cellular and molecular responses of the uterus to embryo implantation can be elicited by locally applied growth factors. PNAS 98 1047-1052.

Pelletier G, Labrie C \& Labrie F 2000 Localization of oestrogen receptor alpha, oestrogen receptor beta and androgen receptors in the rat reproductive organs. Journal of Endocrinology 165 359-370.

Perez MC, Furth EE, Matzumura PD \& Lyttle CR 1996 Role of eosinophils in uterine responses to estrogen. Biology of Reproduction 54 249-254.

Pollard JW 1990 Regulation of polypeptide growth factor synthesis and growth factor-related gene expression in the rat and mouse uterus before and after implantation. Journal of Reproduction and Fertility 88 721-731.

Punyadeera C, Verbost P \& Groothuis P 2003 Oestrogen and progestin responses in human endometrium. Journal of Steroid Biochemistry and Molecular Biology 84 393-410.

Rider V 2002 Progesterone and the control of uterine cell proliferation and differentiation. Frontiers in Bioscience 7 d1545-d1555.

Ross R \& Klebanoff SJ 1966 The eosinophilic leukocyte. Fine structure studies of changes in the uterus during the estrous cycle. Journal of Experimental Medicine 124 653-681.

Rytomaa T 1960 Organ distribution and histochemical properties of eosinophil granulocytes in rat. Acta Pathologica et Microbiologica Scandinavica $\mathbf{5 0} 1-118$.

Shimasaki S, Koga M, Buscaglia ML, Simmons DM, Bicsak TA \& Ling N 1989 Follistatin gene expression in the ovary and extragonadal tissues. Molecular Endocrinology 3 651-659.

Shimasaki S, Moore RK, Otsuka F \& Erickson GF 2004 The bone morphogenetic protein system in mammalian reproduction. Endocrine Reviews 25 72-101.

Solloway MJ, Dudley AT, Bikoff EK, Lyons KM, Hogan BL \& Robertson EJ 1998 Mice lacking Bmp6 function. Developmental Genetics 22 321-339.
Song Q, Mehler MF \& Kessler JA 1998 Bone morphogenetic proteins induce apoptosis and growth factor dependence of cultured sympathoadrenal progenitor cells. Developmental Biology 196 119-127.

Souza CJH, MacDougall C, Campbell BK, McNeilly AS \& Baird DT 2001 The Booroola (FecB) phenotype is associated with a mutation in the bone morphogenetic receptor type $1 \mathrm{~B}$ (BMPR1B) gene. Journal of Endocrinology 169 R1-R6.

Spornitz UM, Rinderknecht BP, Edelmann A, Scheidegger B \& Cairoli F 1994 Ultrastructure as a basis for dating of rat endometrium. Anatomical Record 238 163-176.

Takao M, Hino J, Takeshita N, Konno Y, Nishizawa T, Matsuo H \& Kangawa K 1996 Identification of rat bone morphogenetic protein-3b (BMP-3b), a new member of BMP-3. Biochemical and Biophysical Research Communications 219 656-662.

Takeda K, Oida S, Ichijo H, Iimura T, Maruoka Y, Amagasa T \& Sasaki S 1994 Molecular cloning of rat bone morphogenetic protein (BMP) type IA receptor and its expression during ectopic bone formation induced by BMP. Biochemical and Biophysical Research Communications 204 203-209.

Tchernitchin A 1973 Fine structure of rat uterine eosinophils and the possible role of eosinophils in the mechanism of estrogen action. Journal of Steroid Biochemistry 4 277-282.

Tchernitchin A, Roorijck J, Tchernitchin X, Vandenhende J \& Galand P 1974 Dramatic early increase in uterine eosinophils after oestrogen administration. Nature 248 142-143.

Valenzuela DM, Economides AN, Rojas E, Lamb TM, Nuñez L, Jones P, Lp NY, Espinosa R 3rd, Brannan CI, Gilbert DJ et al. 1995 Identification of mammalian noggin and its expression in the adult nervous system. Journal of Neuroscience 15 6077-6084.

Von Bubnoff A \& Cho KWY 2001 Intracellular BMP signaling regulation in vertebrates: Pathway or network? Developmental Biology $2391-14$.

Wang H, Eriksson H \& Sahlin L 2000 Estrogen receptors $\alpha$ and $\beta$ in the female reproductive tract of the rat during the estrous cycle. Biology of Reproduction 63 1331-1340.

Wathes DC, Reynolds TS, Robinson RS \& Stevenson KR 1998 Role of the insulin-like growth factor system in uterine function and placental development in ruminants. Journal of Dairy Science $\mathbf{8 1}$ 1778-1789.

Willette RN, Gu JL, Lysko PG, Anderson KM, Minehart H \& Yue T 1999 BMP-2 gene expression and effects on human vascular smooth muscle cells. Journal of Vascular Research 36 120-125.

Wilson T, Wu X-Y, Juengel JL, Ross IK, Lumsden JM, Lord EA, Dodds KG, Walling GA, McEwan JC, O'Connell AR et al. 2001 Highly prolific Booroola sheep have a mutation in the intracellular kinase domain of bone morphogenetic protein IB receptor (ALK-6) that is expressed in both oocytes and granulosa cells. Biology of Reproduction 64 1225-1235.

Wozney JM 1998 The bone morphogenetic protein family: multifunctional cellular regulators in the embryo and adult. European Journal of Oral Science 106 160-166.

Wozney JM 2002 Overview of bone morphogenetic proteins. Spine 27 $\mathrm{S} 2-\mathrm{S} 8$.

Wozney JM, Rosen V, Celeste AJ, Mitsock LM, Whitters MJ, Kriz RW, Hewick RM \& Wang EA 1988 Novel regulators of bone formation: Molecular clones and activities. Science 242 1528-1534.

Yan C, Wang P, DeMayo J, DeMayo FJ, Elvin JA, Carino C, Prasad SV, Skinner SS, Dunbar BS, Dube JL et al. 2001 Synergistic roles of bone morphogenetic protein 15 and growth differentiation factor 9 in ovarian function. Molecular Endocrinology 15 854-866.

Yi SE, Daluiski A, Pederson R, Rosen V \& Lyons KM 2000 The type I BMP receptor BMPRIB is required for chondrogenesis in the mouse limb. Development 127 621-630.

Yi SE, LaPolt PS, Yoon BS, Chen JYC, Lu JKH \& Lyons KM 2001 The type I BMP receptor BmprIB is essential for female reproductive function. PNAS $\mathbf{9 8}$ 7994-7999. 
Ying Y \& Zhao G-Q 2000 Detection of multiple bone morphogenetic protein messenger ribonucleic acids and their signal transducer, Smad1, during mouse decidualization. Biology of Reproduction 63 1781-1786.

Zhao G-Q \& Hogan BLM 1996 Evidence that mouse Bmp8a (Op2) and $\mathrm{Bmp} 8 \mathrm{~b}$ are duplicated genes that play a role in spermatogenesis and placental development. Mechanisms of Development 57 159-168.
Zimmerman LB, De Jesus-Escobar JM \& Harland RM 1996 The Spemann organizer signal noggin binds and inactivates bone morphogenetic protein 4. Cell 86 599-606.

Received 30 April 2004

Accepted 11 May 2004 